This item was submitted to Loughborough's Research Repository by the author.

Items in Figshare are protected by copyright, with all rights reserved, unless otherwise indicated.

\title{
Development of self-compacting concrete
}

PLEASE CITE THE PUBLISHED VERSION

http://dx.doi.org/10.1680/stbu.2003.156.4.405

PUBLISHER

(C) ICE Publishing

VERSION

VoR (Version of Record)

LICENCE

CC BY-NC-ND 4.0

REPOSITORY RECORD

Goodier, Chris I.. 2019. "Development of Self-compacting Concrete". figshare.

https://hdl.handle.net/2134/9750. 
This item was submitted to Loughborough's Institutional Repository (https://dspace.lboro.ac.uk/) by the author and is made available under the following Creative Commons Licence conditions.

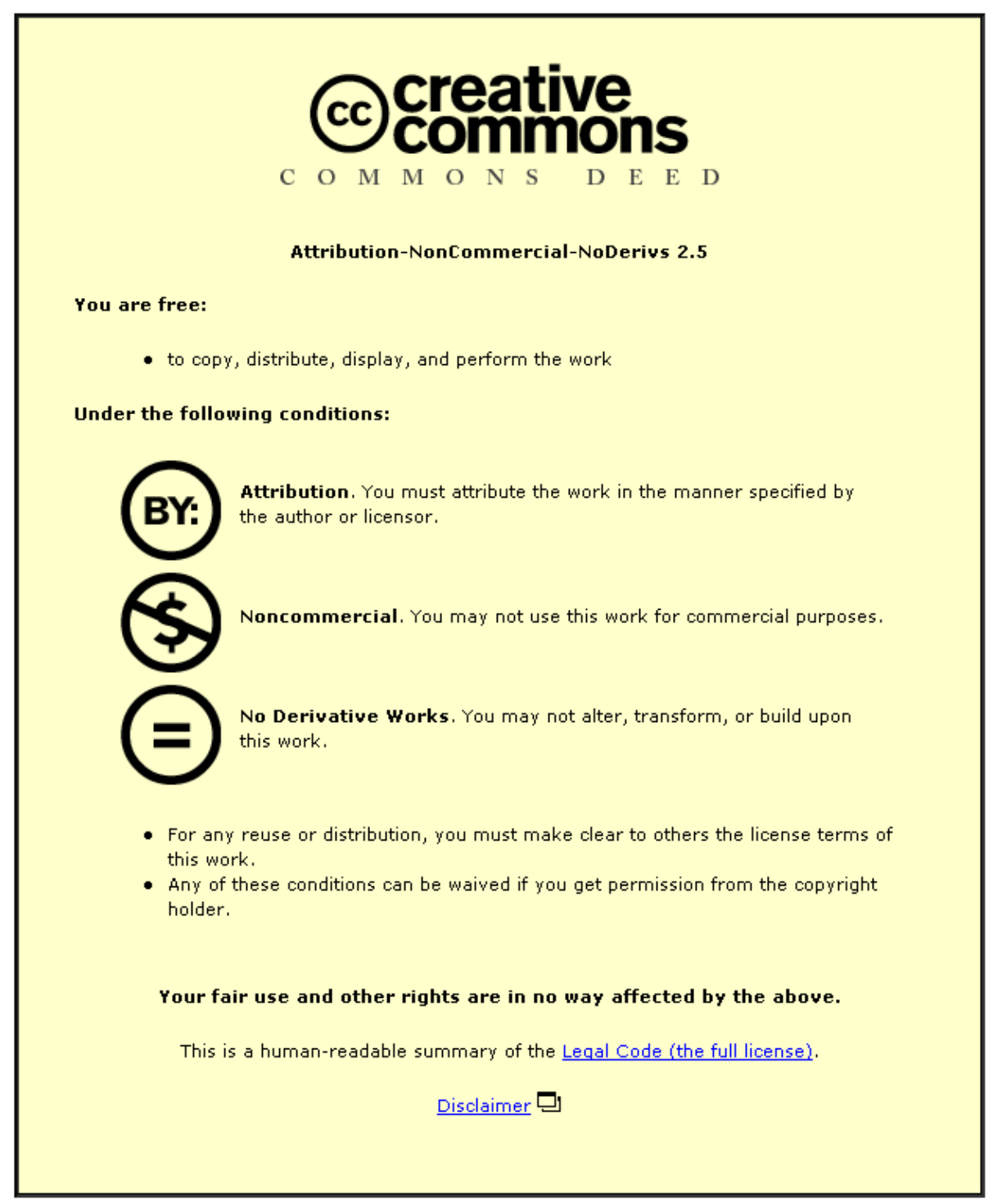

For the full text of this licence, please go to: http://creativecommons.org/licenses/by-nc-nd/2.5/ 


\section{Development of self-compacting concrete}

\section{I. Goodier}

Self-compacting concrete (SCC) can be defined as a fresh concrete which possesses superior flowability under maintained stability (i.e. no segregation) thus allowing self-compaction-that is, material consolidation without addition of energy. It was first developed in Japan in 1988 in order to achieve durable concrete structures by improving quality in the construction process. This was also partly in response to the reduction in the numbers of skilled workers available in the industry. This paper outlines a brief history of SCC from its origins in Japan to the development of the material throughout Europe. Research and development into SCC in the UK and Europe are discussed, together with a look at the future for the material in Europe and the rest of the world. Research and development of SCC is being conducted by private companies (mainly product development), by universities (mainly pure research into the material's properties), by national bodies and working groups (mainly the production of national guidelines and specifications) and at European level (Brite-EuRam and RILEM projects on test methods and the casting of SCC, respectively). Although $\mathrm{SCC}$ is not expected to ever completely replace conventionally vibrated concrete, the use of the material in both the precast and ready-mix markets in the UK, Europe and the rest of the world is expected to continue to increase as the experience and technology improves, the clients demand a higherquality finished product and the availability of skilled labour continues to decrease.

\section{INTRODUCTION}

Self-compacting concrete (SCC) can be defined as a fresh concrete which possesses superior flowability under maintained stability (i.e. no segregation), thus allowing self-compactionthat is, material consolidation without addition of energy. The three properties that characterise a concrete as self-compacting are

- flowing ability-the ability to completely fill all areas and corners of the formwork into which it is placed (e.g. Fig. 1)

- passing ability-the ability to pass through congested reinforcement (e.g. Fig. 2) without separation of the constituents or blocking

- resistance to segregation-the ability to retain the coarse components of the mix in suspension in order to maintain a homogeneous material.

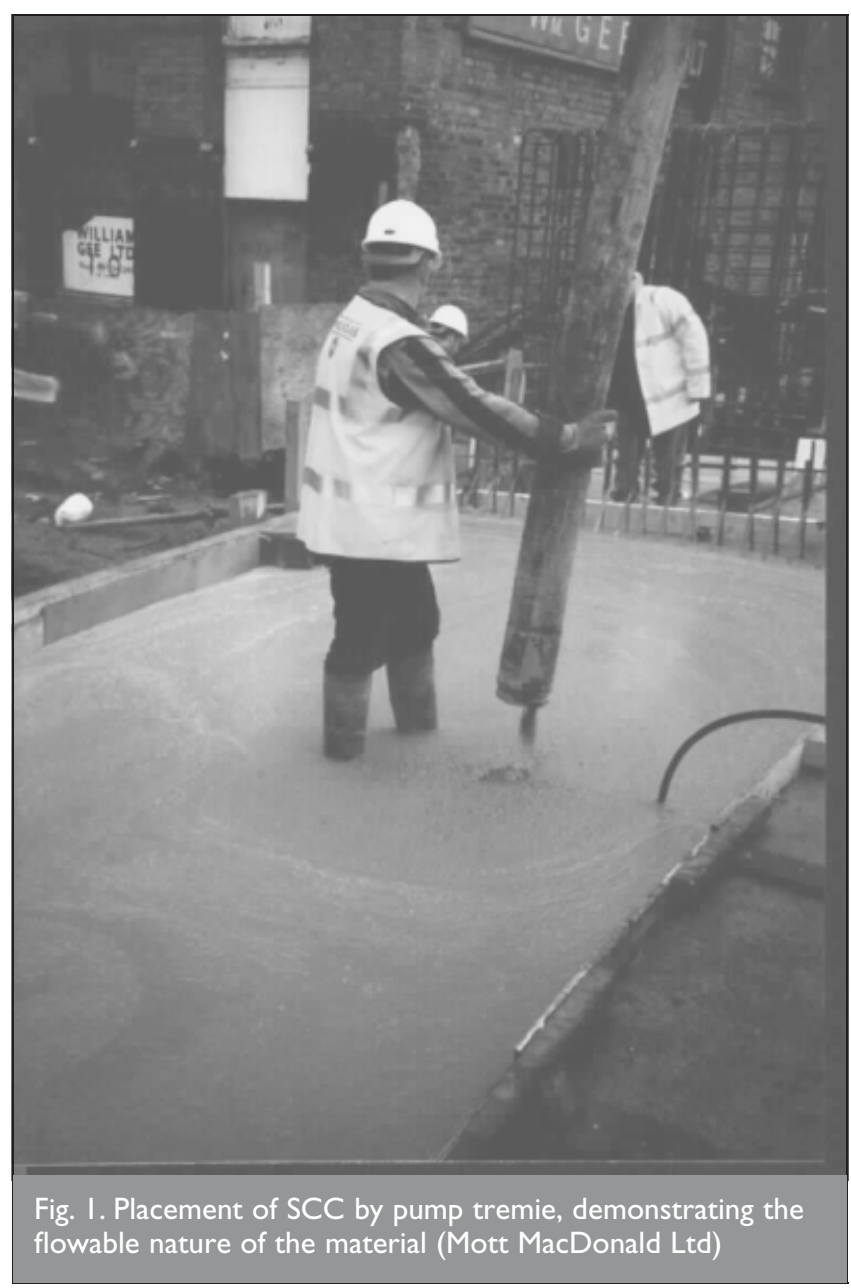

These properties must all be satisfied in order to design an adequate SCC, together with other requirements including those for hardened performance.

SCC was first developed in Japan in 1988 in order to achieve durable concrete structures by improving quality in the construction process. It was also found to offer economic, social and environmental benefits over traditional vibrated concrete construction. Research and development work into SCC in Europe began in Sweden in the 1990s and now nearly all the countries in Europe conduct some form of research and development into the material. 


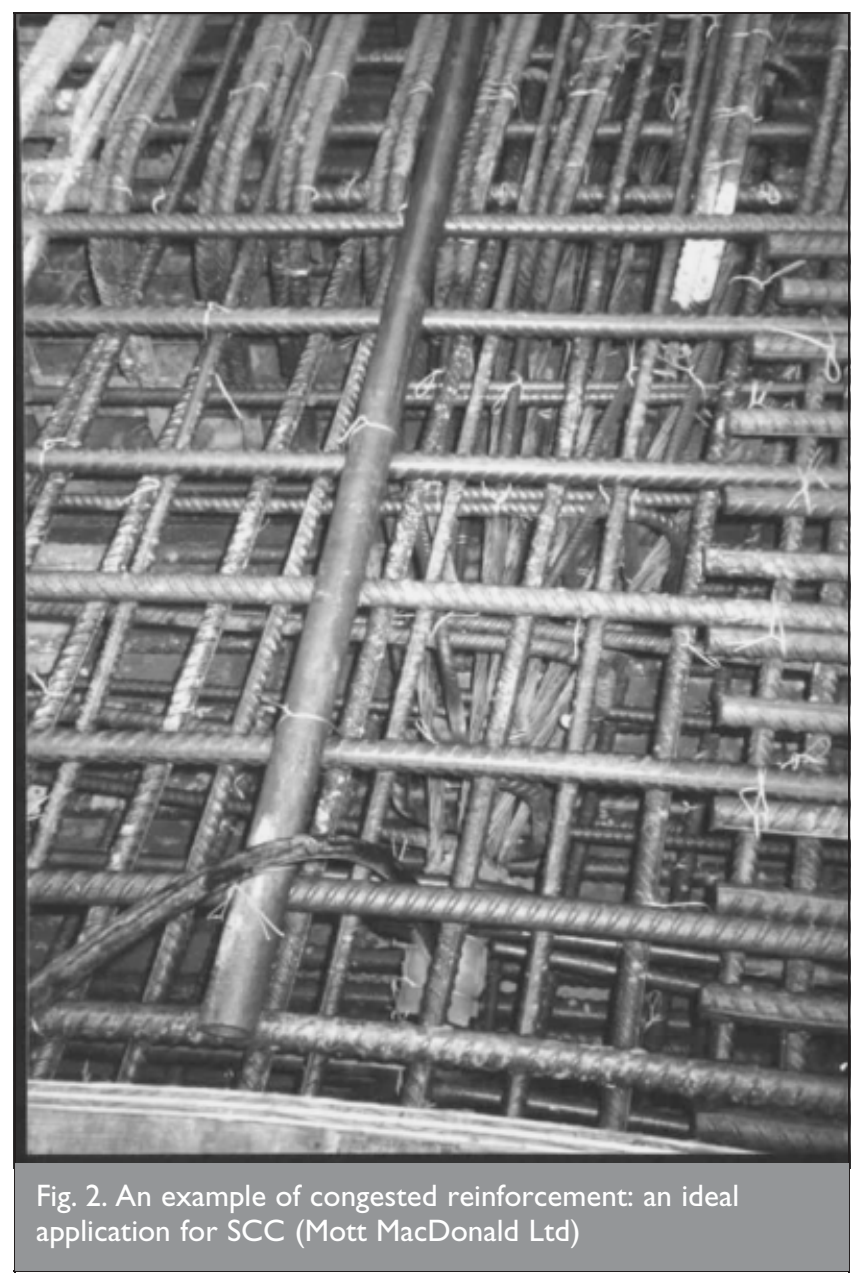

In addition to the benefits described above, SCC is also able to provide a more consistent and superior finished product for the client, with less defects. Another advantage is that less skilled labour is required in order for it to be placed, finished and made good after casting. As the shortage of skilled site labour in construction continues to increase in the UK and many other countries, this is an additional advantage of the material which will become increasingly important.

This paper outlines the history of the development of SCC from its origins in Japan to its development in Sweden and the rest of Europe. The development of the material in Europe is then discussed, with particular reference to the UK.

\section{PROPERTIES OF SCC}

Most materials suitable for conventional concrete can be used in the production of SCC, although there are significant differences in SCC production compared with conventional concrete production. The most important is that the properties of the SCC can be allowed to vary only within much tighter limits. For conventional concrete, variation can be coped with by altering the degree of compaction work, but this is not possible with SCC. The properties of fresh SCC are also much more sensitive to variations in the quality and consistency of the mix constituents. Because of its greater sensitivity to variation, batching accuracy for all component materials is essential for SCC to be successful.

High powder contents are needed in SCC to increase the cohesiveness. Ground granulated blast furnace slag (GGBS), pulverised fuel ash (PFA), or an inert material such as limestone powder are most commonly used. It is possible, however, to produce an SCC without adding any extra fine material.

The placement of SCC is the aspect of the building process that is changed most by the use of SCC. Once the fully compliant SCC is supplied to the point of application then the final operation of casting requires very little skill or manpower compared with traditional concrete to produce uniformly dense concrete. Because of vibration being unnecessary, the noise is reduced and the risk of developing problems due to the use of vibrating equipment is reduced. Fewer operatives are required, but more time is needed to test the concrete before placing.

In general, the hardened properties of SCC are similar or superior to those of equivalent conventional concrete. Provided the self-compacting properties are verified on site, a less variable and denser concrete is achieved. It could also be said that the compaction, and therefore durability, of the concrete is more guaranteed with the use of SCC as it reduces the potential for human error (in the form of poor compaction). The high fines content and the need for well-graded aggregates also improves the concrete, producing a more dense interfacial transition zone between the aggregate and the cement matrix. All these effects are beneficial for both strength and durability, although because of its relatively recent use, knowledge of long-term durability is restricted to a decade of limited use.

At similar water/cement ratios the characteristic strength of SCC is at least equal to that of conventional concrete, and has a similar strength development for the same grade. Due to the low water/cement ratio used in SCC the compressive strength will generally be above $\mathrm{C} 40$ and can be up to C100. The tensile strength is also comparable to the same grade of conventional concrete and drying shrinkage is also similar.

\section{THE HISTORY OF SCC}

The history and development of SCC can be divided into two key stages: its initial development in Japan in the late 1980s and its subsequent introduction into Europe through Sweden in the mid- to late-1990s.

\section{I. Japan}

SCC was first developed in Japan in 1988 in order to achieve more durable concrete structures by improving the quality achieved in the construction process and the placed material. ${ }^{1}$ The removal of the need for compaction of the concrete reduced the potential for durability defects due to inadequate compaction (e.g. honeycombing). The use of SCC was also found to offer economic, social and environmental benefits over traditional vibrated concrete construction. These benefits included faster construction and the elimination of noise due to vibration. One of the main drivers for the development of the technology was the reduction in the number of skilled site operatives that the Japanese construction industry was experiencing in the 1980s. The use of SCC meant that less skilled labour was required for the placing and finishing of the concrete.

SCC was developed from the existing technology used for high workability and underwater concretes, where additional 
cohesiveness is required. The first research publications that looked into the principles required for SCC were from Japan around 1989 to 1991. These studies concentrated upon highperformance and super-workable concretes and their fresh properties such as filling capacity, flowability and resistance to segregation. $^{2-4}$

The first significant publication in which 'modern' SCC was identified is thought to be a paper from the University of Tokyo by Ozawa et al. in 1992..$^{5}$ The term 'self-compacting concrete' is not used within the paper, although a highperformance concrete was produced which possessed all the essential properties of a self-compacting concrete mix.

In the following few years many research papers were published on concretes such as super-workable, self-consolidating, highlyworkable, self-placeable and highly-fluidised concretes, all of which had similar properties to what we now know as SCC. These were mainly papers on work into the mix design of what would become 'SCC' and its associated fresh properties. In 1993, research papers were beginning to be published of case studies on the use of these early forms of 'SCC' in actual applications. ${ }^{6,7}$ One of the first published references utilising the term 'selfcompacting' was in Japan in $1995 .^{8}$

After the development of this prototype SCC, intensive research began in many places in Japan, especially within the research institutes of large construction companies, and as a result, SCC has now been used in many practical applications.

The first significant international workshop dedicated to the material was held at Kochi University of Technology, Japan in August $1998 .{ }^{9}$ The majority of these papers focused upon the development of SCC in different countries, including research and development into mix design models, mix constituents and rheology.

In April 1997, the Japanese Society of Civil Engineers (JSCE) set up a research subcommittee with the aim of establishing recommendations for the practical application of SCC. This was subsequently published in English in August 1999. ${ }^{10}$

The 2nd International Symposium on SCC was organised by the University of Tokyo in October 2001. ${ }^{11}$ A total of 74 papers plus two keynote and four invited speakers from 20 countries were included. Since the 1st International Workshop had concentrated mainly upon mix design and rheology, the 2nd International Symposium concentrated more on the long-term durability and life-cycle cost of SCC.

A conference was recently held in Japan in October 2002 on Concrete Structures in the 21 st Century, which contained six papers on SCC, including four from Japan. ${ }^{12}$ These papers illustrated that the basic technology of the material in Japan is relatively well understood and that the majority of current efforts in research and development are concentrated on taking this knowledge further into new applications such as composite structures and sheet piling.

\subsection{Europe}

In the second half of the 1990s, interest and use of SCC spread from Japan to other countries, including Europe. Some of the first research work to be published from Europe was at an International RILEM (International Union of Testing and Research Laboratories of Materials and Structures) Conference in London in 1996. Papers were presented on the design of SCC by University College London, ${ }^{13}$ and a mix-design model by the Swedish Cement and Concrete Research Institute (CBI). ${ }^{14}$

A Technical Committee (TC 174-SCC) was set up by RILEM in 1997 with the objective of gathering, analysing and presenting a review of the technology of SCC, as well as looking for unified views on testing and evaluation. Seventeen full members and three corresponding members covering ten countries on four continents took part in the work and a stateof-the-art report was published in $2000 .^{15}$

Sweden was the first country in Europe to begin development of SCC, and in 1993 the CBI organised a seminar in Sweden for contractors and producers, leading to a project aimed at studying SCC for housing. ${ }^{16}$ As part of this project, large numbers of half-scale house walls were cast using SCCs which were made with different filler materials. The work from this project contributed to the first European project on SCC which began in January 1997 and was completed in 2000. The main goal of this Brite-EuRam project (BRPR-CT96-0366) was to develop a new vibration-free production system to lower the overall cost of in-situ-cast concrete construction. The first part concerned the development of SCC with or without steel fibres and the second part dealt with full-scale experiments in civil engineering and housing. This project included partners from several European countries, including the UK. For further details, including project summaries see Reference 17. During this time, CBI also developed a mix design model for the design and production of SCC (Fig. 3). ${ }^{16}$

Parallel to this Brite-EuRam project, CBI continued work together with the Swedish National Roads Authority (SNRA) into SCC for bridge casting. Laboratory investigations, prequalifying tests, half-scale trials and finally full-scale trials were all completed. The first of three bridges wholly cast in SCC was completed in January 1998 and is thought to be the first bridge cast with this material outside of Japan (Fig. 4). ${ }^{16}$ This work also showed that the hardened properties of SCC are superior to conventional concrete, including compressive strength, frost resistance, permeability and reinforcement bond strength. This is thought to be mainly due to both the increased cementitious content generally used and the denser interfacial transition zone between the aggregate and the paste of SCCs.

Studies also showed that total bridge building costs can be reduced by as much as $5-15 \%$ when using SCC compared with conventional concrete. ${ }^{16}$ An earlier report on the same work was also published by the SNRA. ${ }^{18}$ This report concluded that as well as reducing overall bridge costs, using SCC has the potential to reduce the energy consumption and emission of greenhouse gases by 20-30\% due to the reduced resources required in the construction process and the enhanced durability of the resultant concrete. However, it does not take into account the likely increased cement content used to make the SCC and the additional energy required for its production.

The first major event dedicated to SCC in Europe was the 1st 


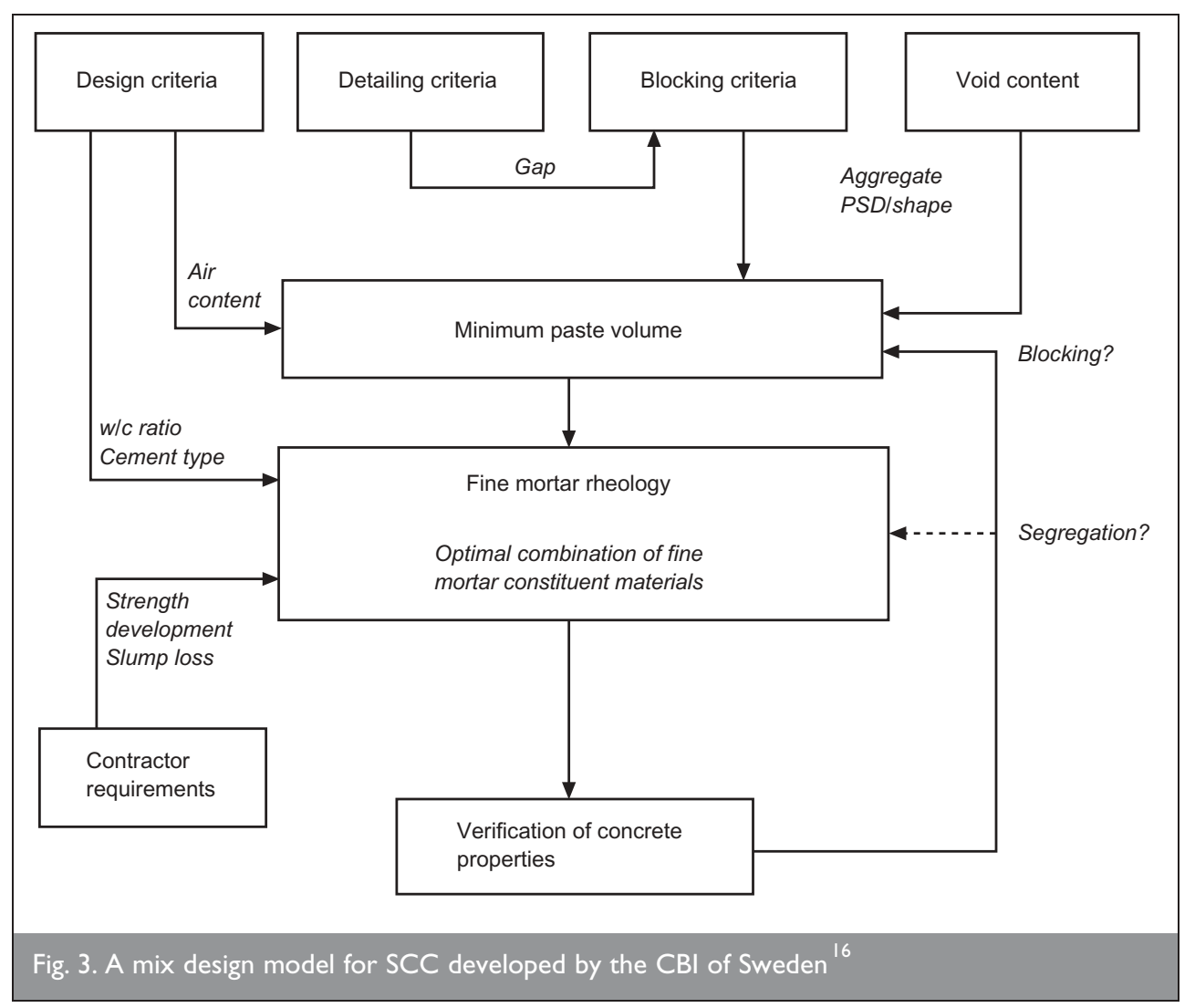

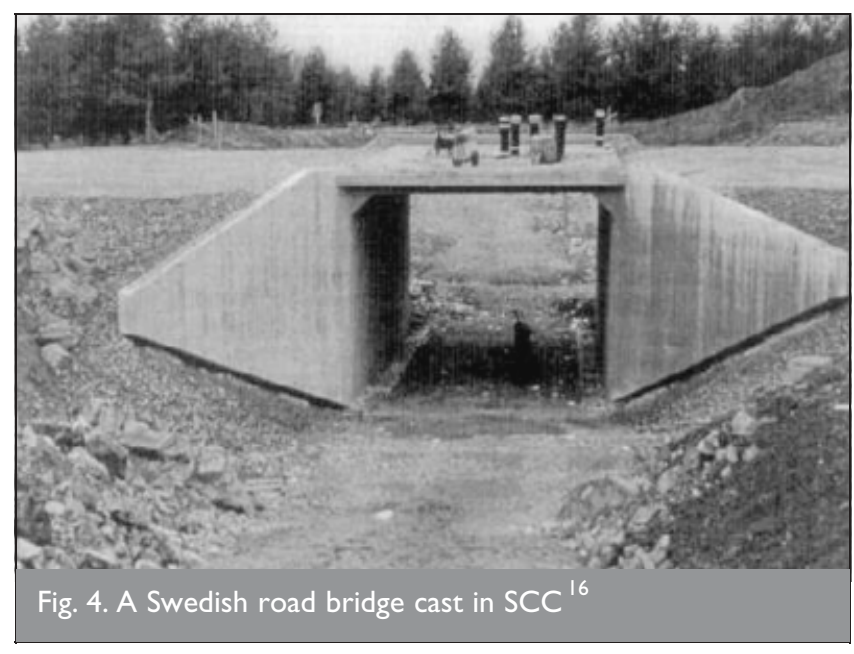

International RILEM Symposium on SCC in Stockholm in 1999. ${ }^{15}$ The papers included 23 from Asia, 38 from Europe, five from North America and one from Australia. The symposium attracted 340 participants from 35 countries, which is a ratio of 5 to 1 of participants to papers, indicating the increasing interest in the material in Europe.

\section{EUROPEAN DEVELOPMENT}

Development and use of SCC began to quickly spread from Sweden to other Scandinavian countries at the end of the 1990s. The concrete industry in countries such as France and the Netherlands have also recently been developing and using the material, with countries such as Germany and the UK progressing closely behind. All of these countries have now used SCC in both in situ and precast applications. Countries such as Greece and the Eastern European countries are still mainly conducting research and development or are at the initial site trial stage.

Two European-wide research projects are currently under way in the field of SCC.

(a) Following the completion of the European-wide SCC BriteEuRam project in 2000, it was clear that the remaining fundamental obstacle to the material's wider use in Europe was the absence of suitable test methods to identify its three key properties (i.e. passing ability, filling ability and resistance to segregation). The EU therefore agreed to support an additional three-year project from 2001 to 2004 through its Growth programme (Growth Project GRD22000-30024) to develop test methods for SCC and to prepare the way for European standardisation. The project involves twelve European partners and is led by the University of Paisley, Scotland. For additional details see Reference 19.

(b) A RILEM committee was also formed in September 2000 to focus on assembling relevant existing knowledge on various aspects on the casting of SCC. ${ }^{20}$ The committee aims to build further on the work of RILEM TC 174-SCC mentioned in the previous section and the objective is to find links between the fundamental basic mechanisms of SCC and the current practical experience regarding SCC. ${ }^{21}$ The knowledge will be further developed through technical discussions and a workshop and will result in a report on the existing available knowledge on the casting of SCC. 
A specification and guideline document has recently been produced by EFNARC (European Federation of Producers and Contractors of Specialist Products for Structures) which aims to provide a framework for the design and use of high-quality SCC in Europe based on the latest research findings combined with field experience. ${ }^{22}$ It is probably the first European guidance document to be universally available, and is freely available on the internet. ${ }^{23}$ It is intended that the document be updated as SCC technology evolves and advances.

Most of the major European countries are currently in the process of developing guidelines or specifications for the use of SCC. Table 1 shows a snapshot of the current stage in the development of SCC guidelines or specifications for each of the European countries listed.

\section{I. Scandinavia}

As described earlier, Sweden was at the forefront of the development of SCC outside Japan and it is estimated that SCC now accounts for approximately $7-10 \%$ of the Swedish readymix market, ${ }^{25}$ up from approximately $3 \%$ in 2000. Currently, the CBI, four universities and the government in Sweden are all conducting research into SCC.

SCC is often used in Sweden today by contractors such as NCC on a commercial basis. ${ }^{26}$ NCC and other Swedish contractors are also conducting research into SCC, both internally and with other companies and universities/institutes. The Swedish Concrete Association (SCA) has also recently published recommendations for the use of SCC. ${ }^{27}$

The volume of SCC produced in Norway has increased from approximately $0.5 \%$ (or $12000 \mathrm{~m}^{3}$ ) of total concrete volume in 2000 to approximately $1 \cdot 2 \%$ (or $29500 \mathrm{~m}^{3}$ ) in $2001 .^{28} \mathrm{~A}$ Norwegian guideline for the production and use of the material was issued in late 2001 and an English translation has recently been completed.

SCC is used in Finland only to a limited degree, although companies such as Lohja Rudus and Parma Betonila each have experience from approximately 10-20 construction sites. ${ }^{29}$ There is also a national project on the practical aspects of SCC led by the Technical University of Helsinki (HUT) and VTT which began in 2001 and will finish in $2003 .^{29}$ No SCC standardisation as yet exists.

Universities in Denmark, such as the DTU (Technical University of Denmark), have also recently undertaken research into SCC, as well as holding training courses on SCC.

The first project investigating SCC in Iceland was from 1996 to 1999 and was a collaboration between the Icelandic Building Research Institute (IBRI) and an Icelandic ready-mix concrete company, Steypustö UNKNOWN SYMBOL 240 FONT=Times New Roman in H. F., which showed that it was possible to cast SCC in Iceland with Icelandic materials. ${ }^{37}$ IBRI continue to conduct research into SCC and they are hosting the 3rd International Symposium on SCC in August 2003. ${ }^{38}$

\subsection{France}

France is quite active in the research and development of SCC. ${ }^{30}$ A national research project on SCC called BAP (Bétons auto-plaçants) is currently ongoing. French recommendations for the use of the material were established in July $2000^{31}$ and are used as reference on construction sites.

The Lafarge Group have conducted a large amount of research and development at their Laboratoire Central de Recherches (LCR) at L'Isle d'Abeau, near Lyon. Their progress in the development of SCC is approximately two years ahead of the position in the UK. They have spent approximately £2 million on researching and developing the material internationally and currently produce approximately $50000 \mathrm{~m}^{3}$ /annum of SCC, with this volume increasing almost exponentially at present. ${ }^{32}$

The Lafarge Group wanted to validate the assumption that using SCC generates an overall cost saving. They therefore worked with a contractor to simultaneously construct two identical apartment buildings in Nanterre, France. Conventional concrete methods were used for one building and for the second building the construction process was adapted to utilise SCC materials and processes. The building constructed using SCC materials and processes was completed 2.5 months before

\begin{tabular}{|c|c|c|c|}
\hline Country & Guideline organisation & Acceptance phase & Publication date \\
\hline Austria & $\mathrm{n} / \mathrm{a}$ & Draft & $2002^{*}$ \\
\hline Denmark & $\mathrm{n} / \mathrm{a}$ & Draft in preparation & $\mathrm{n} / \mathrm{a}$ \\
\hline Europe & EFNARC & Guideline & 2002 \\
\hline Finland & $\mathrm{n} / \mathrm{a}$ & Draft & $2003^{*}$ \\
\hline France & AFGC & Industry recommendation & 2000 \\
\hline Germany & Annex to DIN 1045 & For comment & $2003 *$ \\
\hline \multirow[t]{2}{*}{ Italy } & Annex to EN 206 & For comment & $2003^{*}$ \\
\hline & Italian Ready-mix Assoc. & In preparation & $\mathrm{n} / \mathrm{a}$ \\
\hline \multirow[t]{2}{*}{ Netherlands } & BRL I80| & Approval & 2002 \\
\hline & TC $73 / 04$ & Accepted & 2001 \\
\hline Norway & Norwegian Concrete Society & Accepted & 2002 \\
\hline Sweden & Swedish Concrete Assoc. (SCA) & Accepted & 2002 \\
\hline \multicolumn{4}{|l|}{${ }^{*}$ Expected } \\
\hline
\end{tabular}


the conventionally constructed building and with an overall project cost saving of $21 \cdot 4 \%$. $^{33}$

\subsection{Germany}

In Germany, SCC requires technical approval before it can be used on site. ${ }^{34}$ The current DIN standards do not allow this type of concrete to be used because the consistency and the fines content do not comply with the standard. Therefore, the DIBt (German Institute of Technical Approvals in Berlin) requires suitability tests from a third-party laboratory, usually universities, who then issue an official approval. Many contractors have obtained approvals and are constructing with SCC.

At least six different universities and research establishments in Germany are also conducting research into SCC. The University of Stuttgart is also involved with the current European-wide SCC test methods project (Growth GRD2-200030024).

\subsection{Belgium}

A Belgian national contact group on SCC exists chaired by Professor De Schutter of the University of Ghent. ${ }^{35}$ This group of universities, contractors, suppliers and other interested parties meet several times a year to discuss SCC development in Belgium.

Several national research projects on SCC are also currently under way, funded mainly by the National Fund for Scientific Research, Flanders, and other interested parties. These projects are investigating the transport of potentially aggressive media in SCC, the spalling behaviour of SCC and the integration of SCC into the building industry.

\subsection{Spain}

SCC production is just beginning in Spain, but the first structures have already been constructed in Malaga, Valencia and Madrid. The current problem is that SCC is not included in the basic Spanish regulations for concrete, and so care has to taken and its use fully justified. Instituto Eduardo Torroja de Ciencias de la Construcción (CSIC) is leading the standardisation group for SCC in the Spanish National Standardisation Agency (AENOR). ${ }^{36}$ The target is to issue some Spanish standards on SCC by the end of 2002. They are also collaborating with other Spanish research groups such as UPC (Universitat Politècnica de Catalunya) in Barcelona.

\subsection{Holland}

The precast concrete industry in the Netherlands first became interested in SCC in 1998. A project was begun to develop SCC precast applications by the Belton Group, ${ }^{39}$ an association of 24 precasters, which is a subsidiary of BFBN (Association of the Dutch Concrete and Precasting Industry). Although the Belton project was formally completed in December 1999, intensive collaboration in SCC is still continuing. In 2002 a total volume of $250000 \mathrm{~m}^{3}$ of precast SCC is expected to be produced $^{40}$ and approximately 30 companies have been certified for the production of SCC pre-cast elements. ${ }^{24}$

Guidelines for ready-mix SCC are finished and are expected to be approved by the end of 2002, at which point the certification of ready-mix plants can begin. ${ }^{24}$ Currently, readymix SCC is being used, but mainly for demonstration projects.

\subsection{Switzerland}

SCC currently accounts for approximately $1 \%$ of the ready-mix concrete market in Switzerland and the material has largely been developed by trial and error. ${ }^{41}$ The use of SCC is currently not limited by Swiss standards because the standards apply to performance and not the composition of concrete. Research into SCC has been conducted at the Swiss Federal Institute of Technology (ETH) in Zurich and at the EMPA (Swiss Federal Institute for Materials Testing and Research) in Dübendorf. ${ }^{41}$

\subsection{Italy}

In Italy the majority of SCC applications are in the precast market, although SCC has been used for in situ applications. The Italian Standards Institute has just completed a document on SCC, which is now being considered as a Standard (as an annex to EN 206-1). ${ }^{42}$ The Italian Ready-Mixed Concrete Producers Association is also preparing guidelines on SCC.

\subsection{Other European countries}

Other countries in Europe such as the Czech Republic and Greece are also beginning to research and construct with SCC. A bridge abutment and an experimental tunnel lining have both been cast with SCC in Prague ${ }^{43}$ and a trial was held for the use of SCC in the $2.5 \mathrm{~km}$ cable-stayed bridge over the Corinthian Gulf in Greece. ${ }^{44}$

\section{UK DEVELOPMENT}

Until about four years ago, interest in SCC in the UK was largely confined to research studies at Paisley University and University College London (UCL). There has, however, been a rapid increase in interest from UK industry in the last three years. Two of the first site applications were in 2000 for the Midsummer Place shopping centre extension in Milton Keynes and the Millennium Point project in Birmingham.

The Concrete Society in the UK formed a working party early in 1999 consisting of 18 experts from universities, suppliers, producers, designers and contractors with the aim to maintain a watching brief on the impact and uptake of SCC in the UK. They have recently produced both an information sheet ${ }^{45}$ and Part 1 of a Current Practice Sheet. ${ }^{46}$ The Part 1 report deals with materials, properties, production and placing of SCC. At the time of writing, Part 2, which will cover production, placing and optimisation of the construction process, was $90 \%$ complete.

A three-year research project into SCC in the UK is also currently being conducted by the Building Research Establishment's (BRE) Centre for Concrete Construction. This work is funded by the UK Department of Trade and Industry's (DTI's) Construction Industry Directorate. The aim of the project is to encourage the wider use of SCC by the UK construction industry, and to demonstrate the economic, social and environmental advantages it offers over traditional vibrated concrete construction. The work involves consulting with UK industry on its perceptions of SCC, researching the production of SCC mixes suited to industry needs and disseminating this and additional information through demonstration events and the publication of case studies and guidance material. 


\section{I. Academic institutions}

The leading academic institution in the UK with regard to SCC is the Advanced Concrete and Masonry Centre at the University of Paisley. ${ }^{47}$ This team is led by Professor Bartos and also includes John Gibbs and Dr Mohammed Sonebi. They were key members of the original Brite-EuRam project (BRPR-CT960366) mentioned in the previous section and are leading the current European-wide project on test methods. In addition, Professor Bartos is Chairman and John Gibbs the Secretary of the Concrete Society Working Party on SCC. Paisley University also began an 18-month Government-funded research project in December 2001 aimed at reducing the cost of SCC and encouraging its use in general construction.

As mentioned earlier, the other academic institution in the UK with a history of research into SCC is University College London (UCL). The work into SCC is being coordinated by $\mathrm{Dr}$ Peter Domone, who is also a member of the Concrete Society Working Party on SCC. UCL is also involved with the European-wide project on the testing of SCC.

Dundee University's Concrete Technology Unit has also recently begun a three-year research project investigating the formwork pressures generated by SCCs and other specialist concretes. ${ }^{48}$ This project will determine if the current CIRIA formwork pressure recommendations are applicable to current new materials and types of concrete such as SCC, and if not, safe design pressures will be established.

\subsection{Concrete producers}

RMC Ready-mix Ltd is the UK's leading supplier of readymixed concrete. The company has been undertaking development work on SCC since 1998 with the aim of producing mix design criteria for materials local to any of their 325 batching plants throughout the UK. ${ }^{49}$ It was originally thought that the material would be a niche product, but RMC is now concentrating upon developing more economical mixes to enable the material to be more universally used. ${ }^{50}$ This development is targeted at customer needs in terms of the application, strength requirement and other technical factors that may be specified.

Lafarge Aggregates Ltd have been conducting research and development into SCC in France for several years, and it is now available at each of their plants in the UK. Lafarge produce their own family of admixtures especially for the production of SCC, called Agilia. These products are fully developed and are all currently available and Lafarge see the next step as getting these existing products accepted and used by the market. ${ }^{32}$

Tarmac Topmix Ltd first began researching and developing SCC in 1998 and first started using it at their precast factory at Tallington in $1999 .^{51}$ The first ready-mixed SCC was supplied in 2000 and the eventual aim is to make it available at all plants in the country.

\subsection{Admixture suppliers}

Sika Ltd launched Sika ViscoCrete in the UK in 1998, which was the first admixture on the UK market specifically for producing SCC. Six different types are available and it can be used with either retarders or accelerators. Other admixture manufactures have now followed this lead. MBT and Grace
Construction Products both produce admixtures for the UK SCC market, including superplasticisers, viscosity-modifying admixtures and specialist admixtures for precast applications. The ready-mix companies RMC and Lafarge produce their own admixtures for SCC.

\subsection{Consultants}

Consultants in the UK do not generally undertake any concrete research or development directly, but do sometimes sponsor or collaborate in research projects at universities and research organisations. Mott MacDonald have an established track record with the development of specifications and guidance notes for SCC and are a member of the Concrete Society Working Party on SCC. They have also worked closely with ready-mix suppliers and contractors to use the material on a variety of projects throughout the UK. ${ }^{52}$ However, many UK consultants are cautious when specifying SCC due to the lack of existing guidance, standards and test methods and the lack of an established track record for the material.

\subsection{Contractors}

Contractors in the UK generally rely upon the ready-mix supplier for any expertise in SCC mix design. However, knowledge and appreciation of the material among contractors is slowly increasing as the use of SCC becomes more widespread.

John Doyle Construction are probably the leading contractor in the UK in the use of SCC and are involved in several research and development projects such as the European SCC test methods project and the project on formwork pressures at Dundee University. ${ }^{53}$ They have used the material several times in the UK in actual applications such as column encasement and basements, although its use is still job-specific. Site trials are always conducted before SCC is used in the intended structure.

Other contractors have used SCC in the UK but its use is still job-specific, often to solve a problem during construction such as congested reinforcement.

\subsection{UK precasters}

Aarsleff Piling's Balderton premises claim to be the UK's first user of SCC in precast pile production. ${ }^{54}$ An SCC mix was developed in partnership with RMC with a compressive strength of 26-28 MPa at only $16 \mathrm{~h}$. At nine days the $50 \mathrm{MPa}$ mark had been passed and the piles could be driven. Aarsleff have also won a $£ 4 \cdot 25$ million contract to supply and install approximately 3000 precast concrete piles for the Channel Tunnel Rail Link. ${ }^{55}$ SCC was used for these piles and casting began in June 2002 with installation beginning the following month.

Tarmac Precast Concrete Ltd are also now using SCC at their three UK precast plants. SCC currently accounts for approximately $65 \%$ of bespoke production at their Tallington plant and their long-term objective is to convert fully to SCC when economics and practicalities allow. ${ }^{56}$ Current contracts are for prison units (Fig. 5), double-T beams and columns (Fig. 6).

Trent Concrete Ltd in Nottingham have been experimenting 

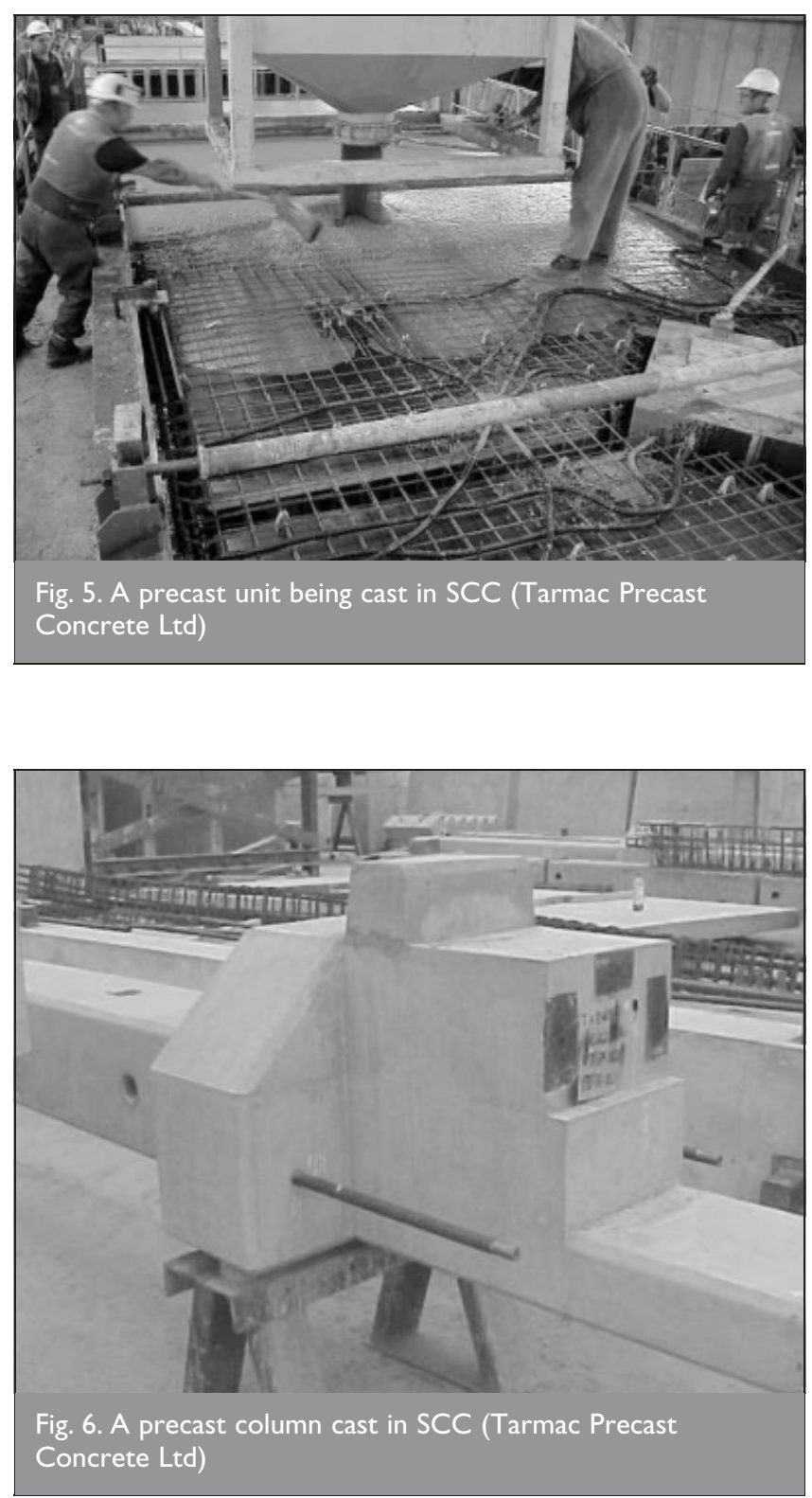

with SCC for the last two years and production using the material first began in August 2002. ${ }^{57}$

\subsection{Seminars and events}

The SCI (Society of Chemical Industry) held a seminar on SCC in January 2001 in London. Approximately 60 delegates attended and the speakers were the main practitioners of SCC in the UK from the areas of research (Professor P. Bartos), design (Dr N. Henderson), ready-mix (R. Gaimster) and contracting (P. Goring). This meeting was one of the first events in the UK to begin to introduce the material to members of the construction industry who had no experience or knowledge of SCC.

A demonstration and international workshop on SCC, lasting a total of two and a half days, was held at the Advanced Concrete and Masonry Centre at Paisley University in May/ June, 2001. ${ }^{58}$ The event was attended by 70 delegates from eleven countries and helped raise the awareness and knowledge of the material in Scotland and the rest of the UK.

Four demonstration events on SCC around the UK have also recently been held by BRE's Centre for Concrete Construction as part of their DTI-funded project on SCC, which combined practical demonstrations with presentations by industry experts on SCC. The events were aimed at people in the industry with little or no knowledge of the material, with more than 140 people attending the four events.

\section{THE FUTURE}

From its origins in Japan in the late 1980s, research, development and use of SCC has spread steadily throughout the world. Approximately 7-10\% of the Swedish ready-mix market is now SCC and research is being conducted in virtually every country in Europe. National working groups on the material now exist in some form in most countries in Europe, with the majority of them working towards producing some form of guidance on the use of SCC.

Large amounts of research and development are now also being conducted in Canada and the USA at places such as the University of Sherbrooke and the Universite Laval. The first North American conference on SCC was held in November 2002 by Northwestern University. American concrete organisations such as the American Concrete Institute (ACI), American Society for Testing and Materials (ASTM) and PCI (Precast/Prestressed Concrete Institute) have all recently formed committees to produce guidelines, standards and specifications for SCC. The material is slowly gaining acceptance in this huge market and already it is estimated that approximately 4000$5000 \mathrm{~m}^{3}$ is used per day in precast applications in North America. Nearly $100000 \mathrm{~m}^{3}$ of ready-mixed SCC has also so far been used in North America. ${ }^{59}$

Countries such as Argentina, Australia and New Zealand are also all now beginning to conduct research and development work into SCC, with more countries sure to follow. A third International Symposium on SCC is being held in Iceland in August 2003, where much of the research and development work presently under way will be presented. For further details see Reference 60.

The main barrier to the increased use of SCC in the UK and Europe seems to be the lack of experience of the process, and the lack of published guidance, codes and specifications. This situation will improve, however, as experience and knowledge increases and each country begins to produce its own guidance and specifications.

Precasters are currently the overwhelming users of SCC in the UK, in Europe and in the USA. This is partly due to them owning and operating the on-site batching plant, and so they are able to take full advantage of all the potential benefits of SCC. They can also minimise or control the potential disadvantages of the material (such as inconsistency of supply and site acceptance). In the countries where SCC has been adopted relatively quickly, such as Japan and Sweden, the ready-mix concrete producers are owned or operated by the contractors, therefore the increased material costs can be directly offset by savings in the construction process, in a similar way to precast production.

Although SCC is not expected to ever completely replace conventionally vibrated concrete, the use of the material in 
both the precast and ready-mix markets in the UK, Europe and the rest of the world is expected to continue to increase. The main drivers for this increase in use are expected to include

- an increase in the experience of both producers, contractors, designers and clients

- an increase in available guidance on the production, design and use of SCC

- a decrease in the unit cost of the material as technology and experience improves

- the demand from clients for a higher-quality finished product

- the decrease in skilled labour available in many countries for both the placing and finishing of concrete.

\section{ACKNOWLEDGEMENTS}

The author wishes to acknowledge the support provided in collating the information for this paper from the BRE Framework contract on SCC, which is currently being undertaken by BRE for the Construction Industry Directorate, DTI. The author also wishes to thank the industry participants in this programme, including BCA, Concrete Admixtures Association, Concrete Society, John Doyle Construction Ltd, Lafarge UK Ltd, Mott MacDonald Ltd, RMC Readymix Ltd and the University of Paisley, as well as the many individuals who have supplied the information required in the writing of this paper.

\section{REFERENCES}

1. OKAMURA H., OZAWA K. and OUCHI M. Self-compacting concrete. Structural Concrete, 2000, 1, No.1, Mar., 3-17.

2. TANigaWA Y., Mori H., YoneZAWA T., IZUMI I. and MitSUI K. Evaluation of the flowability of high-strength concrete by L-flow test. Proceedings of the Annual Conference of the Architectural Institute of Japan, 1989/1990.

3. OzAWA K., MAEKAWA K. and OKAMURA H. High performance concrete with high filling ability. Proceedings of the RILEM Symposium, Admixtures for Concrete, Barcelona, 1990.

4. TANGTermsirikul S., SaKamoto J., Shindoh T. and MATSUOKA Y. Evaluation of resistance to segregation of super workable concrete and the role of a new type of viscosity agent. Reports of the Technical Research Institution, 1991, Taise: Corporation, Japan, No. 24, pp. 369-376.

5. Ozawa K., Maekawa K. and OKamura H. Development of High Performance Concrete. University of Tokyo, 1992, Faculty of Engineering journal.

6. SAKAMOTO J., MATSUOKA Y., SHINDOH T. and TANGTERMSIRIKUL S. Application of super workable concrete to actual construction. Proceedings of Concrete 2000 Conference, University of Dundee, 1993.

7. Kuroiwa S., MatsuoKa Y., HaYAKAWA M. and SHINDOH T. Application of Super Workable Concrete to Construction of a 20-storey Building. ACI, 1993, SP-140.

8. OZAWA K., SAKATA N. and OKAMURA H. Evaluation of selfcompactability of fresh concrete using the funnel test. Concrete Library of JSCE, No. 25, 1995.

9. OUCHI M. and OzAWA K. (eds). Proceedings of the International Workshop on Self-Compacting Concrete, Kochi, 1998, Japan Society of Civil Engineers, ISBN 4-8106-0310-5.
10. Uомото T. and OzAwA K. (eds). Recommendation for SCC. JSCE Concrete Engineering, Series 31, Tokyo, Japan, 1999.

11. OZAWA K. and OuCHI M. (eds). Proceedings of the $2 n d$ International Symposium on Self-Compacting Concrete, Tokyo, 2001, 743, ISBN 4-90154-04-0 (www.infra.kochitech.ac.jp/sccnet/scc2/).

12. Fib concrete structures in the 21st century. Proceedings of the 1st Fib Congress, Osaka, 2002 (www.fib2002.com/e/ index.html).

13. Domone P. L. and CHAi H. W. Design and testing of SCC: Production methods and workability of concrete.

Proceedings of an International RILEM Conference. E \& F N Spon, London, 1996, ISBN 419220704.

14. Petersson 0. and BILlberg P. A model for SCC: Production methods and workability of concrete. International RILEM Conference. E \& F N Spon, London, 1996, ISBN 419220704.

15. Skarendahl A. and Petersson Ö. (eds). Proceedings of the 1st International RILEM Symposium on SCC. RILEM Publications, 1999, p. 786, ISBN 2-912143-09-8.

16. BILLBERG P. Self-compacting concrete for civil engineering structures-the Swedish experience. Swedish Cement and Concrete Research Institute, Stockholm, 1999, CBI report 2:99, p. 80.

17. Details available on the internet at: http://scc.ce.luth.se.

18. NILSSON M. Project on Self-compacting Bridge Concrete. Swedish National Road Administration (SNRA), 1998, Publication 1998:71 E, ISSN 1401-9612, p. 19.

19. Details available on the internet at: www.acmcentre.com/testing-scc/index.php.

20. RILEM. TC CSC: Casting of SCC, www.rilem.ens-cachan.fr/csc.

21. BILlberg P. CBI, Sweden. Personal communication, November 2002.

22. EUROPEAN FEDERATION of PRODUCERS AND CONTRACTORS OF SPECIALIST PRODUCTS FOR STRUCTURES. Specification and Guidelines for SCC. EFNARC, 2002, ISBN 0-9539733-4-4, p. 29.

23. EUROPEAN FEDERATION OF PROdUCERS AND CONTRACTORS OF SPECIALIST PRODUCTS For STRUCTURES (EFNARC). Specifications and Guidelines for Self-Compacting Concrete. EFNARC, Surrey, 2002. Also available on the internet at: www.efnarc.org.

24. DingenouTs M. Review of SCC Product Acceptance Standardisation. Proceedings of Paisley University Workshop, September 2002.

25. SKARENDAHL A. Swedish Construction Sector Innovation Centre, BIC. Personal communication, August 2002.

26. GRAUERS M. NCC Construction Sverige AB, NCC Engineering, Sweden. Personal communication, July 2002.

27. SWEDISH CONCRETE ASSOCIATION. SCC Recommendations for Use, SCA, 2002, Report series No. 10, p. 84.

28. JoHANSEN K. Sintef, Trondheim, Norway. Personal communication, August 2002.

29. KUKKo H. VTT Building and Transport, Finland. Personal communication, September 2002.

30. De LARRARD F. Laboratoire Central des Ponts et Chaussées, France. Personal communication, July 2002.

31. Association Française de Genie Civil. Bétons Autoplaçants: Recommandations provisoires. AFGC, Bagneux, France, July 2000. 
32. RichARDSON G. Lafarge Aggregates Ltd. Personal communication, July 2002.

33. RICHARDSON G. SCC Demonstration. BRE, Watford, October 2002.

34. ReInhardt H. W. University of Stuttgart. Personal communication, July 2002.

35. De Schutter G. Magnel Laboratory for Concrete Research, Ghent University. Personal communication, August 2002.

36. Revuelta D. Instituto Eduardo Torroja de Ciencias de la Construcción (CSIC), Madrid, July 2002.

37. NíELSSON I. Icelandic Building Research Institute (IBRI). Personal communication, July 2002.

38. ICELANDIC BUILDING RESEARCH InSTITUTE. For details of 3rd International Symposium see www.ibri.is/scc.

39. BELTON GROUP. For further details of SCC project see www.belton.nl.

40. BENNENK W. and VAN SCHIJNDEL J. SCC in the daily pre-cast concrete practice. Proceedings of the 17th International Congress of Pre-cast Concrete Industry, Istanbul, 2002.

41. LeEmann A. Swiss Federal Institute for Materials Testing and Research (EMPA). Personal communication, July 2002.

42. KhURANA R. MBT. Personal communication, July 2002.

43. ViteK J. L. Metrostav a.s., Czech Republic. Personal communication, August 2002.

44. KANAKARI H. K. Bridging the north-south divide. Concrete Engineering, 2001, 5, No. 2, 6-8, 10-12.

45. CONCRETE SOCIETY. Self-compacting concrete. Concrete Magazine, supplement, 2001, 35, No. 1.

46. GAIMSTER R. and GIBBS J. Self-compacting concrete current practice sheet No.123. Concrete, 2001, July/August, 32-34.

47. AdVANCED CONCRETE AND MASONRY Centre. For more details see www.acmcentre.com.

48. DundeE University Concrete Technology Unit. Details available at: www.dundee.ac.uk/civileng/research/concrete/ formwork 1.htm.

49. GAIMSTER R. and FOORD C. Self-compacting concrete. Concrete, 2000, April, 23-25.

50. HARTLEY A. RMC Ready-mix Ltd. Personal communication, August 2002.

51. Sealey B. Tarmac. Personal communication, October 2002.

52. Henderson N. Mott MacDonald. Personal communication, July 2002.

53. GoRing P. John Doyle Construction. Personal communication, July 2002.

54. PARKER D. Star of the cast takes mould breaking role. New Civil Engineer, October 2000, pp. 33-34.

55. Concrete Engineering InTERnational (CEI). Pre-cast Piling Contract. CEI, 2002, p. 65.

56. RichaRdS C. Tarmac Pre-cast Concrete Ltd. Personal communication, August 2001.

57. Downing M. Trent Concrete. Personal communication, September 2002.

58. BARTOS P. Self-compacting concrete demonstration and international workshop. Concrete, 2001, July/August, 30-31.

59. VACHON M. and DACZKo J. U.S. Regulatory Work on SCC. Proceedings of the 1st North American Conference on the Design and Use of Self-Consolidating Concrete (SCC), Rosemont, Illinois, USA, 2002, 423-426.

60. Details available at: www.ibri.is/scc.

Please email, fax or post your discussion contributions to the secretary by I May 2004: email: daniela.wong@ice.org.uk; fax: +44 (0)20 7799 1325; or post to Daniela Wong, Journals Department, Institution of Civil Engineers, I-7 Great George Street, London SWIP 3AA. 